\title{
DETECTION OF SALMONELLA TYPHIMURIUM IN THE MILK OF NORTH SINAI SHAMI GOATS BY PCR AMPLIFICATION OF THE INVA GENE SEQUENCE
}

\author{
Y. M. Kamel and H. M. El-Shaer
}

Animal and Poultry Production Division, Desert Research Center, El-Mataria, Cairo, Egypt

\section{SUMMARY}

Salmonella Species are widely distributed in the environment, and cause salmonellosis in humans and animals. Salmonella typhimurium often transmit to humans through milk and dairy products. A collection of 50 milk samples from North Sinai Damscus (Shami) goats were examined for detection of Salmonella typhimurium by both convenential cultural and PCR methods. PCR was performed by amplification of nucleotide sequence within the InvA gene of Salmonella typhimurium. It was found that 5 samples (10\%) were positive by standard culturing method while 7 samples (14\%) were positive by using PCR technique from which 2 samples were positive by $P C R$ assay but negative with culturing. The remaining samples were negative by both PCR and bacteriological culture. PCR technique was shown to be an effective, rapid, reliable and sensitive method for detection of Salmonella typhimurium than the conventional cultural method.

Keywords: Shami goats, Salmonella typhimurium, milk, PCR, InvA

\section{INTRODUCTION}

Salmonella is the most prevalent food poisoning microorganism. Members of the genous Salmonella are gram negative and facultative anaerobic, rod shape bacteria (Le Minor, 1992). Salmonella species are widely distributed in the environment, and cause salmonellosis in humans and animals. Milk as a food of animal origin, is frequently implicated in human infection because the high prevalence of Salmonella strains in domestic animals (International Association of Microbiological Society, 1978). The established culture based methods used to detect Salmonellae in milk are laborious; need intensive culture technique, time consuming and often not specific enough. The standard methods used today for analyzing Salmonellae involve preenrichment in buffered peptone water (BPW), selective enrichment in Rappaport Vassiliadis soy broth, plating on selective agar and subsequent identification by biochemical tests and then confirmed serologically (Charlotta et al., 2004).

The complete test requires three to four days to obtain a negative result and up to seven days to get a confirmed positive result (Anomymous, 1995). This is not parallel with the control of infection which depends mainly on the accuracy of rapid methods and precise diagnostic tests for monitoring the infection. For this purpose several rapid methods have been developed. These methods include enzyme-linked immunosorbant assays using polyvalent, polycolonal or monocolonal antibodies (Krysinki, 1977 and Mottingly, 1984) against somatic or flagellar antigens and DNA 
hybridization assays using polynucleotide or oligonucleotide probe. Morever, there are still problems with their sensitivity and specificity. The PCR technique in particular has been found to be highly specific molecular diagnostic tool (Rahn et al., 1992 and Hoorfar et al., 2000) in which a few copies of target DNA can be amplified to a level detectable by gel electrophoresis (Rassmussen et al., 1994).

The pathogenicity of Salmonella species is dependant upon the ability of these organisms to invade and gain access to cells that are normally non phagocytic. The gene which responsible for this character of pathogenicity is a chromosomal encoded locus, InvA, has been determined (Galan and Crutiss, 1991), in addition, InvA gene is present and functional in most, if not all, virulent salmonella strains. So, The study was designed to develop and apply a simple, rapid and sensitive polymerase chain reaction (PCR) based protocol for routine detection of viable Salmonella in contaminated milk samples depending on the presence of InvA gene.

\section{MATERIALS AND METHODS}

\section{Bacterial strain}

Salmonella typhimurium strain was obtained from American Type Culture Ciollection (ATCC), catalogue No., 25566, Parklawn Drive, Rockville, USA. The strain, grown in tryptone soy broth (Oxoid LTD, Basingstoke, Hampshire, UK) at $37^{\circ} \mathrm{C}$ for $24 \mathrm{~h}$, was washed three times by means of centrifugation $(8,000 \mathrm{Xg}$ for 8 min) in a $0.8 \% \mathrm{NaCl}$ solution.

\section{Collection of raw milk samples}

Fifty milk samples were collected; udder halves were cleaned and disinfected prior to sampling. The first three squirts of milk were discarded from each teat and samples were collected into $250 \mathrm{ml}$ sterile bottles and transmitted to the laboratory for biological examination and DNA extraction.

\section{Bacteriological examination}

The obtained milk samples were pre-enriched by placing of $25 \mathrm{ml}$ from each milk sample in a sterile flask with $225 \mathrm{ml}$ of $1 \%$ buffered peptone water (BPW) and incubated at $37^{\circ} \mathrm{C}$ for 24 hours (Poemla and Silliker, 1976). The samples were enriched by inoculation of $0.1 \mathrm{ml}$ from each pre-enriched sample in $10 \mathrm{ml}$ of Rappabort Vassiliadis (Merck) broth and $1 \mathrm{ml}$ to tetrathionate broth (Merck) and incubated at $42^{\circ} \mathrm{C}$ and $37{ }^{\circ} \mathrm{C}$ for 24 hours respectively. One loopful of both cultures were streaked onto XLD (Oxoid) and SS agar (Oxoid) media. The plates were incubated at $37^{\circ} \mathrm{C}$ for $24 \mathrm{~h}$. Presumptively positive colonies, red colonies with black center from XLD agar and creamy ones from SS agar were picked up and inoculated into Triple sugar iron agar (Oxoid), Motility indole urea agar (Oxoid) and Simmon's citrate agar (Oxoid). All plates and tubes were incubated at $37^{\circ} \mathrm{C}$ for $24 \mathrm{~h}$. At least two colonies were selected and streaked into two separate slope agar tunes for biochemical identification which was done according to Edwards and Ewing, 1972 and Cruickshank et al., 1975. Confirmation was done serologically by using Salmonella polyvalent $\mathrm{O}$ and $\mathrm{H}$ agglutination sera obtained from Staten Serum Institute (SSI), Copenhagen, Denmark. 
Serological examination: according to Kauffman, 1974

Isolates that the preliminary identified biochemically as salmonella were subjected to serological identification according to Kauffman white scheme, suspected salmonella isolates were cultured on nutrient agar slopes for 24 hours at $37^{\circ} \mathrm{C}$. Then, subjected to the following examinations:

\section{Slide agglutination technique:}

A loopful was suspended in a drop of physiological saline solution on a slide, so as to make a homogenous suspension. A drop of salmonella anti-sera was added to the suspension with a standard loop and mixed thoroughly to bring the organisms in close contact with anti-sera. Positive agglutination occurred within a minute and could be easily seen with the naked eye. A delayed or partial agglutination was considered as negative or false.

\section{A- Determination of " $O$ " somatic antigen}

Polyvalent "O" anti-sera were first tried to assure that the suspected isolates are salmonella. Positive cultures were then tested with each of the "O" grouping sera followed by the respective mono-specific "O" anti-sera factor in order to determine the complete antigenic formula.

\section{B- Determination of " $H$ " flagella antigen}

Polyvalent " $\mathrm{H}$ " anti-sera for both phase 1 and phase 2 were applied to determine the antigenic formula of the isolates.

\section{DNA extraction from milk}

Each milk sample $(10 \mathrm{ml})$ was pretreated with one $\mathrm{ml}$ of $25 \%$ sodium citrate. The DNA was extracted using a modification of the method described previously by Drake et al., 1996. Briefly, petroleum ether (2ml), 100\% ethanol (2ml) and saturated ammonium hydroxide $(4 \mathrm{ml})$ were added, mixed, and the solution centrifuged at $8000 \mathrm{~g}$ for $10 \mathrm{~min}$ at room temperature. The supernatant was discarded and the pellet resuspended in 500-900 $\mu \mathrm{l}$ STET buffer ( $80 \%$ sucrose, $0.5 \%$ Triton-X-100, 50mmol EDTA, $50 \mathrm{mmol}$ Tris- $\mathrm{HCl}$ at $\mathrm{pH} 8.0$ ) and transferred to a $2 \mathrm{ml}$ microcentrifuged tube. The tube was vortexed occasionally for $10 \mathrm{~min}$. An equal volume of phenol, chloroform and isoamyl alcohol was added, mixed, and the tube centrifuged at $17000 \mathrm{~g}$ for $10 \mathrm{~min}$ at room temperature. The supernatant fluid was transferred to a new tube and an equal volume of chloroform was added, mixed, and centrifuged as above. The clear aqueous phase was pipetted to a new tube and the DNA precipitated with 0.1 volume 3 molar sodium acetate, $\mathrm{pH} \mathrm{5.4,1}$ volume cold isopropanol and $30 \mu \mathrm{g}$ glycogen. The sample was centrifuged at $12000 \mathrm{~g}$ for $30 \mathrm{~min}$ at room temperature to pellet the DNA. The air dried pellet was resuspended in $15 \mu \mathrm{l}$ nuclease-free water and quantified at $260 \mathrm{~nm}$ using UV spectrophotometer.

\section{PCR design and amplification conditions}

Primers were selected from the published sequence of InvA gene of Salmonella as described previously (Rhan et al., 1992), were synthesized in Bio-Synthesis, for InvA1 with sequence 5' ACA GTG CTC GTT TAC GAC CTG AAT 3', and for InvA2 with sequence 5' AGA CGA CTG GTA CTG ATC GAT AAT3'. InvA1 and InvA2 were used for amplify the amplified fragment of 284 base-pair level. From 
pure culture or genomic DNAs of Salmonella typhimurium, amplification of the InvA gene was achieved on the thermocycler (model 9600, Perkin-Elmer) as follows: 20 cycles of PCR, with 1 cycle consisting of 1 min at $94^{\circ} \mathrm{C}$ (denaturation), 30 seconds at $58^{\circ} \mathrm{C}$ (annealing), and $1 \mathrm{~min}$ at $72^{\circ} \mathrm{C}$ (primer extension). An additional cycle of $1 \mathrm{~min}$ at $94^{\circ} \mathrm{C}, 30$ seconds at $58^{\circ} \mathrm{C}$, and $5 \mathrm{~min}$ at $72^{\circ} \mathrm{C}$ was also included. A $25 \mu \mathrm{PCR}$ mixture contained the following: $50 \mathrm{mM}$ Tris- $\mathrm{HCl}(\mathrm{pH} 8.3) ; 200 \mathrm{uM}$ (each) dATP, $\mathrm{dCTP}, \mathrm{dGTP}$ and dTTP; $0.075 \mu \mathrm{M}$ (each) primer; $0.65 \mu$ of AmpliTaq; and $2.5 \mathrm{mu}$ $\mathrm{MgCl}_{2}$. Genomic DNA at a concentration of $4 \mathrm{ng} / \mathrm{ul}$, a single colony, or cells from serially diluted sample of Salmonella were used in the PCR mixture. Salmonella choleraesuis subsp. choleraesuis (smith) Weldin serotype typhimurium deposited as Salmonella typhimurium (ATCC 25566) was used as a positive control. A template control (sterile water) was included to monitor contamination of the PCR reagents in each PCR assay.

\section{RESULTS}

Total 50 milk samples were collected from Shami goats in North Sinai governorate and examined by the PCR- based detection system for Salmonella typhimurium. The target PCR product at 275 bp (fig:1) was amplified in a total of 7 samples (14\%) while Salmonella typhimurium was isolated by culturing in 5 samples only $(10 \%)$ as illustrated in table (1). Comparing results of PCR and that of conventional cultural assays (table 2), it was found that 5 samples in both PCR and culture were positive, 2 samples were positive by PCR assay but negative with culturing. The remaining 43 samples were negative by both PCR and bacteriological culture.

Table 1. Frequency of isolation of $S$. typhimurium from milk samples by conventional cultural technique and PCR

\begin{tabular}{lcccc}
\hline \multirow{2}{*}{ No. of samples } & Conventional & \multicolumn{3}{c}{ PCR } \\
\cline { 2 - 5 } & No. & $\%$ & No. & $\%$ \\
\hline 50 & 5 & 10 & 7 & 14 \\
\hline
\end{tabular}

Table 2. Comparative analysis between the PCR and conventional cultural technique for $S$. typhimurium

\begin{tabular}{llll}
\hline Culture & PCR & No. & $\%$ \\
\cline { 2 - 4 }$+\mathrm{Ve}$ & $+\mathrm{Ve}$ & 5 & 10 \\
& $-\mathrm{Ve}$ & 0 & 0 \\
$-\mathrm{Ve}$ & $+\mathrm{Ve}$ & 2 & $\varepsilon$ \\
No. of examined samples & $-\mathrm{Ve}$ & 43 & 86 \\
\hline
\end{tabular}




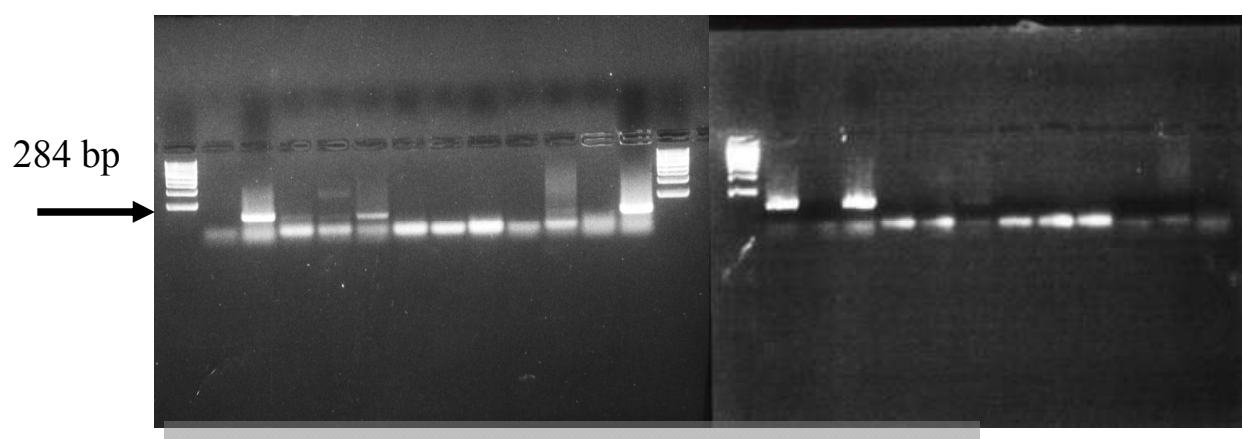

Figure 1. PCR amplification of DNAs from milk samples. Lanes:1, 14 \&15 1 kb DNA ladder; 4, 5, 6,11, 13, 16 \& 18 are positive samples for S.typhimurium and Lanes 7, $8,9,10,12,17 \& 20-28$ are negative samples while Lane 3 showing positive control and Lane 2 negative control (no DNA).

\section{DISCUSSION}

Milk and milk by products captured a great importance because they are one of the cheapest source of animal protein and are of high nutritive value, palatability and digestibility. This importance increased in desert and new reclaimed areas such as North Sinai governorate where the Bedouins depend mainly on the goat's milk and its by-products. Unfortunately, Milk as a highly nutritive substrate for growth of many microorganisms especially in low hygienic areas, may contain multiple bacteria species of major public health significance. Salmonella species are the most important microorganism that threat the human health where Salmonella species were identified in $84.5 \%$ of the outbreaks for which a causative agent was reported (Schmidt et al., 1995).

Several obstacles are encountered when analuzying Salmonellae in milk samples, namely law concentration and uneven distribution in the milk (Charlotto et al., 2004). Polymerase chain reaction (PCR) is a molecular biology technique which has taken up as increasingly significant space in the field of laboratory diagnostics, allowing the detection of many pathogens such as Listeria monocytogenes, Campylobacter sp., Yersinea enterocolitica, Vibrio cholera, Shigella flexneri, Escherichia coli and Salmonella in different kinds of food such as meat and milk (Luciana et al., 2001). Moreover, PCR method able to detect Salmonella even in poorly contaminated products (Luciana et al., 2004).

One of the critical points of the PCR technique used in the choice of the sequence to be amplified, which must be common to most of the serovars and do not present homology with other organisms. In our study, when using primers which are derived from gene InvA and code for proteins related to cell invasion, a specific amplification of DNA of Salmonella was observed at $284 \mathrm{bp}$ as shown in figure (1). The figure shows lacking of non specific bands during amplification plus the lack of false positive results makes this method unique and indicating high specificity of this PCR assays. This appeared to be similar to results obtained by Wang et al., 1997 and Rhan 
et al., 1992 who studding 630 isolates of Salmonella species including Salmonella typhimurium, amplified all samples of salmonella, except $S$. Litchfield and $S$. senftenberg. In the outhers' opinion, the apparent absence of gene InvA in these two serovars suggests that these organisms are not invasive, or that they have alternative pathways to penetrate cells with an as yet unknown pathogenic potential.

However, in the present study two primers which specifically amplify an $284 \mathrm{bp}$ fragment in strains of the genus salmonella were selected and synthesized. The primers were selected completely internal to the InavA gene. By selecting primers completely internal to the InavA gene, all non Salmonella strains responded negatively to the amplicon of InvA gene.

All samples were cultured according to conventional technique by using procedure outlined in Material and Method, and the data cleary indicate the accordance between the results of the biochemical methods and PCR as shown in table (2). Comparing results of PCR and that of conventional culture assays (table 1\&2). PCR was shown to be more sensitive in Salmonella typhimurium detection than culture method as the latter method yield 5 samples positive only. The difference in the positive result between the two methods may attributed to the sensitivity of the PCR assay as it could be detected very law number of Salmonella typhimurium up to 1 cell $/ 25 \mathrm{ml}$ of milk and this in agreement with the results obtained by Moffezzoli et al., 1995.

The results confirm that the InvA gene is unique to detect Salmonella strains and PCR assay serve as an effective, rapid reliable and sensitive technique for the detection of Salmonella strains.

\section{ACKNOWLEDGMENT}

This research was supported under Grant No., M18-001, Middle East Regional Cooperation (MERC) program, Bureau for Economic Growth, Agriculture and Trade, U. S. Agency for International Development.

\section{REFERENCES}

Anonymous, 1995. Microbiology - General guidance on methods for the detection of Salmonella. CSN ISO 6579.

Charlotta Lofstrom, Rickard Knutsson, Charlotta Engdahl Axelsson, and Peter Radstrom, 2004: Applied and Enviromental Microbiology, Jan. P. 69-75.

Cruickshank R., J. Duguid, B. Mormion and R. Swain, 1975: The practice of medical microbiology. $12^{\text {th }}$ Ed. Churchill, Edinburgh.

Drake M.A., C.L. Small, K.D. Spence and B.G. Swanson, 1996. Rapid detection and identification of Lactobacillus spp. in dairy products by using the polymerase chain reaction. Journal of food protection 59, 1031-1036.

Edwards P. R. and W. H. Ewing, 1972. Identification of entero- bacteriaceae. Minnoapolis, Burgers, Publ. Co. USA.

Galan J. E. and R. Curtiss III. 1991. Distribution of the invA, -B, -C, and-D genes of Salmonella typhimurium among other Salmonella serovars: invA mutants of Salmonella typhimurium are deficient for entry into mammalian cells. Infect. Immun. 59:2901-2908. 
Hoorfar, J., P. Ahrens, and P. Radstrom, 2000 Automated 5' nuclease PCR assay for identification of Salmonella enterica. J. Clin. Microbiol. 38: 3429-3435.

International Association of Microbiological Socities. 1978. Microorganisms in foods, vol. 11, p. 160-172. International Association of Microbiological Socities, Tornoto.

Kauffmann G., 1974: Kauffmann white scheme. WHO, BD172, 1, Rev. Acta. Path. Microb. Sci., 61: 385.

Krysinski, E. P., and R. C. Heimsch, 1977. Use of enzyme labeled antibodies to detect Salmonella in foods. Appl. Environ. Microbiol. 33:974-954.

Le Minor M., 1992. The genus Salmonella, p. 2760-2774. In A.

Luciana C., D. Elisabetta, V. Giulia, D.M. Dario and P. Giuseppe, 2004. Comparison of PCR, electrochemical enzyme-linked immunosorbent assays, and the standered culture method for detecting Salmonella in meat products. Applied and Enviromental Microbiology, Mar. P. 1393-1396.

Luciana R. S., P. N. Viadimer, D. O. Silvia, L. F. Maristela, P. P. Alexandre, R. Aldemir, T.S. Carios and F. L. Rul, 2001. Polymerase chain reaction (PCR) for the detection of Salmonella in artificially inoculated chicken meat. Rev. Inst. Med. S. Paulo, 43 (5): 247-250, September-October.

Moffezzoli I., A. Galli, R. Caldarelli, E.O. Zotini and P. Ferrante, 1995. Detection of Salmonella spp. in food by polymerase chain reaction. Annali Di Microb. Ed Enzimo., 45: 165-172.

Mottingly J.A., 1984. Enzyme linked immunosorbent assay for detection of all salmonella using a combination of myeloma protein and hybridoma antibody. J. Immunol. Methods 73:147-156.

Niederhauser C., U. Candrian, C. Hofelein, M. Jermini, H.P. Buhler and J. Lulhy, 1992. Use of polymerase chain reaction for detection of Listeria monocytogenes in food. Appl. Environ. Microbiol., 58: 1564-1568.

Poemla P.K. and J. Silliker, 1976. Salmonella in compendium of methods for microbiological examination of foods. Am. Pub. Health Ass. Washington.

Rassmussen S. R., H. B. Rassmussen L. R. Larsen, R. Hoff-Jorgesen, and R. Cano, 1994. Combined polymerase reaction hybridization microplate assy used to detect leukemia virus and Salmonella. Clin. Chem. 40:200-205.

Rahn K., S. A. De Grandis and R. C. Clarke, 1992. Amplification of an inv A gene sequence of Salmonella typhimurium by polymerase chain reaction as a specific method of detection of Salmonella. Mol. Cell. Probes, 6: 271-279.

Schmidt H., L. Beutin and H. Karch, 1995. Molecular analysis of the plasmid encoded hemolysin of Escherichia coli O157:H7 strain EDL 933.Infect. Immun., 63: 10551061.

Wang R. F., W.W. Cao and C.E. Cerniglia, 1997. A universal protocol for PCR detection of 13 species of food borne pathogens in foods. J. of Appl. Microbiol., 83: 727-736. 
الكثف عن ميكروب السالمونيلا تيفيميوريم في حليب الماعز الثامي بثمال سيناء InvA باستخدام تفاعل البلمرة المتسلسل بتكبير تتابع جين ياسر محمود كامل و حسن محمد الثناعر

$$
\text { شعبة الإتتاج الحيوانسي والدواجن - مركز بحوث الصحراء - المطرية - الثاهة. }
$$

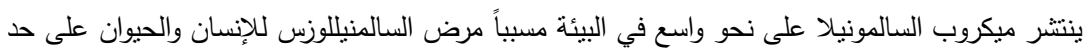

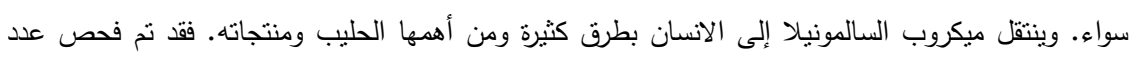

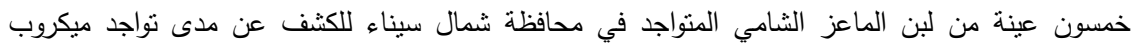

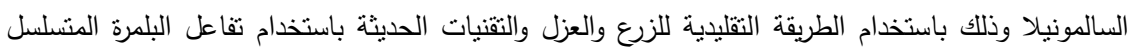

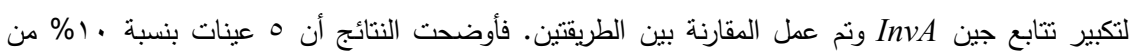

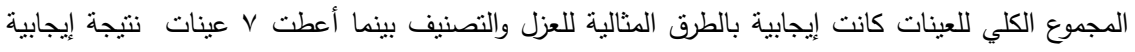

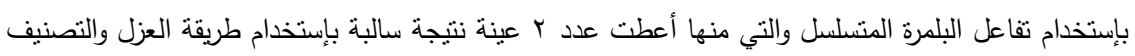

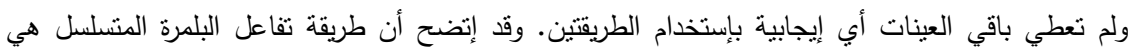
الأكثر دقة وسرعة وفعالية في الكثف عن ميكروب السالمونيلا. 